\title{
HUBUNGAN BEBAN KERJA DENGAN TINDAKAN PENCEGAHAN CEDERA TERTUSUK JARUM SUNTIK PADA PERAWAT DI RSU BETHESDA GMIM TOMOHON
}

\author{
Rafika Mokodompit \\ Diana V. D. Doda \\ Gresty N.M Masi \\ Program Studi Ilmu Keperawatan Fakultas Kedokteran \\ Universitas Sam Ratulangi \\ Email : Rafikamokodompit24@gmail.com
}

\begin{abstract}
Workload appears when there is an interaction between task demands, work environment, competency, behaviour, and perceptions of the worker. It can be defined as well as professionalism in many factors, for example the tasks that they must fulfill. The aim of this research is to know the relation between workload and preventing needle-stick injuries at GMIM Bethesda Public Hospital Tomohon. Research method: this research uses a quantitative method with cross-sectional correlational approach by using chi square test with 64 people as the population. Total sampling method is used. Conclusion: According to the result using chi square statistic test, it shows that there is a relation between workload and needle-stick injuries at GMIM Bethesda Public Hospital Tomohon with significant values $=0.000<$ a 0.05 .
\end{abstract}

Keywords: Workloads, Preventing Needle-stick Injury.

Abstrak : Beban kerja merupakan sesuatu yang muncul dari interaksi antara tuntutan tugastugas, lingkungan kerja dimana digunakan sebagai tempat kerja, keterampilan, perilaku dan persepsi dari pekerja. Beban kerja juga dapat didefinisikan secara profesional pada berbagai faktor seperti tuntutan tugas atau upaya-upaya yang dilakukan untuk melakukan pekerjaan. Tujuan Penelitian : untuk mengetahui hubungan antara beban kerja dengan tindakan pencegahan cedera tertusuk jarum suntik Di RSU Bethesda GMIM Tomohon. Metode Penelitian ini menggunakan jenis penelitian kuantitatif dengan metode Cross Sectional korelasional,dengan menggunakan uji chi-square jumlah populasi yang di ambil sebanyak 64 orang dengan. Sampel yang digunakan dengan metode total sampling. Kesimpulan berdasarka hasil analisis dengan menggunakan uji statistik Chi-Square menunjukan terdapat hubungan antara beban kerja dengan tindakan pencegahan cedera tertusuk jarum suntik Di RSU Bethesda GMIM Tomohon. dengan nilai signifikan $=0.000$ atau kurang dari $\alpha 0.05$.

Kata Kunci : Beban Kerja, Pencegahan Cedera Tertusuk Jarum

\section{PENDAHULUAN}

Keperawatan merupakan suatu bentuk layanan kesehatan profesional yang merupakan bagian integral dari layanan kesehatan yang didasarkan pada ilmu dan kiat keperawatan. Fungsi utama perawat adalah membantu klien, baik dalam kondisi sakit maupun sehat, guna mencapai derajat kesehatan yang optimal melalui layanan keperawatan. Layanan keperawatan diberikan karena adanya kelemahan fisik , mental, dan keterbatasan pengetahuan (Asmadi, 2008). Tenaga keperawatan merupakan tenaga kesehatan terbanyak di rumah sakit dan memiliki kontak yang paling lama dengan pasien. Perawat memiliki jenis pekerjaan yang beresiko kontak dengan zat infeksius misalnya darah, cairan tubuh pasien, ataupun tertusuk jarum suntik bekas pasien, dan benda lain yang dapat menjadi media penularan penyakit. 
Perawat sebagai tenaga kesehatan merupakan sumber daya yang penting di rumah sakit dan sangat dibutuhkan untuk mencapai pelayanan rumah sakit yang optimal (Pangalila, 2017). Seorang perawat memiliki tugas dan tanggung jawab yang cukup besar dimana dia harus merawat seorang pasien meliputi bio-psiko dan spiritual sehingga seorang perawat memiliki beban kerja yang cukup berat.

Beban kerja perawat yang bekerja di rumah sakit berkaitan dengan asuhan keperawatan yang harus diberikan kepada pasien. Ha-hal yang menjadi pertimbangan dalam beban kerja perawat adalah jumlah pasien yang tidak sebanding dengan jumlah pasien yang dirawat, aktivitas keperawatan langsung, tidak langsung dan pendidikan kesehatan serta rata-rata waktunya, dan frekuensu tindakan yang dibutuhkan pasien. (Runtu, 2018). Perawat dalam melayani klien dituntut untuk memberikan waktu dan tenaga dalam memenuhi setiap kebutuhan dasar klien. Dengan adanya tanggung jawab akan berdampak dan mempengaruhi pada beban kerja perawat. Beban kerja perawat adalah seluruh kegiatan atau aktivitas yang dilakukan oleh seorang perawat selama bertugas di suatu unit pelayanan keperawatan (Sumangando, dkk 2017). Terdapat beberapa hal yang mempengaruhi beban kerja perawat adalah kondisi pasien yang selalu berubah, jumlah rata-rata jam perawatan yang di butuhkan untuk memberikan pelayanan langsung pada pasien, serta banyaknya tugas tambahan yang harus dikerjakan oleh seorang perawat (Sumangando,dkk 2017). Beban kerja berlebihan akan mempengaruhi kemampuan perawat dalam bekerja sesuai dengan prosedur yang aman. Ketika perawat tanpa sengaja menusuk dirinya sendiri dengan jarum suntik yang sebelumnya masuk ke dalam jaringan tubuh pasien, perawat berisiko terjangkit sekurang-kurangnya dua patogen potensial. Dua patogen yaitu hepatitis B
(HBV) dan menyebabkan masalah ialah virus Human

Immunodeficiency Virus (HIV) Selain itu juga rawan adalah saat petugas kesehatan melakukan recapping (memasukan dengan tangan jarum suntik bekas pakai pada tutupnya sebelum dibuang) (pangalila 2017).

Hasil wawancara dengan salah satu perawat di RSU Bethesda GMIM Tomohon mengatakan bahwa beban kerja terasa cukup tinggi karena mereka diharuskan untuk merawat pasien secara menyeluruh dan jumlah pemanding antara perawat dan pasien tidak sebanding jumlah perawat di setiap ruang saat sift kurang lebih 4-5 orang tetapi jumlah pasien yang datang melebihi dari jumlah perawat tersebut. Hal ini dibuktikan dengan data yang didapati du ruangan yehezkiel dimana dalam satu shift perawat dapat menangani empat pasien perawat diruangan tersebut juga mengatakan bahwa kejadian tertusuk jarum suntik pernah terjadi pada perawat karena perawat memiliki beban kerja yang lebih banyak dengan pasien. Terutama untuk perawat baru Hal ini dikarenakan suasana lingkungan yang baru dan rasa gugup terhadap senior. Berdasarkan uraian tersebut peneliti merasa tertarik untuk melakukan penelitian tentang hubungan antara beban kerja dengan tertusuk jarum suntik sehingga dapat mengurangi kejadian cedera tertusuk jarum suntik Di RSU Bethesda GMIM Tomohon.

\section{METODE PENELITIAN}

Penelitian ini menggunakan jenis penelitian kuantitatif dengan metode Cross Sectional korelasional, yaitu penelitian yang bertujuan untuk mengetahui hubungan atau pengaruh antara dua atau lebih variabel penelitian dengan pendekatan Cross Sectional yaitu diukur dan diukur dalam waktu bersamaan. (Siswanto, dkk 2016). Penelitian ini telah dilaksanakan di RSU Bethesda GMIM Tomohon. Penelitian ini dilaksanakan pada Desember 2018- Maret 
2019. Populasi adalah keseluruhan subyek penelitian yang akan diteliti. populasi dalam penelitian ini sebanyak 64 perawat. Instrumen pada penelitian ini berupa kuesioner. Pada bagian awal instrumen penelitian berisi data karakteristik responden yang terdiri dari initial responden, umur, jenis kelamin, Pada bagian kedua berisi variabel independen yaitu pencegahan cedera tertusuk jarum suntik dan variabel dependen berisi beban kerja perawat. Kuisoner yang dibuat untuk mengukur variabel independen beban kerja, terdiri dari 13 pernyataan berisikan empat alternatif. Penentuan skor jawaban beban kerja yaitu tidak menjadi beban kerja 1, beban kerja ringan 2, beban kerja sedang 3 , beban kerja berat 4 . untuk cedera tertusuk jarum suntik mengunakan kuesioner yang terdiri dari 9 pertanyaan dengan bobot jika Ya diberi skor 1 dan Tidak diberi skor 0 . Skor pada Cedera tertusuk jarum suntik ditentukan dengan menggunakan rumus $C u t$ Off Point.

Uji valid dalam penelitian ini dilakukan atau divalidasi oleh salah satu staf dosen di Program Studi Ilmu Keperawatan Fakultas Kedokteran Universitas Sam Ratulangi. Peneliti terlebih dahulu membagikan kuesioner kepada responden. Responden yang diambil berjumlah 20 responden yang berada di puskesmas inobonto yang ditentukan berdasarkan kriteria inklusi. Kuesioner tersebut terdiri dari 2 variabel, pada bagian pertama berisi karakteristik responden (inisial responden, umur, pendidikan, jenis kelamin, unit kerja/ruangan), sedangkan pada bagian kedua berisi pernyataan dari setiap variabel. Variabel independen (Beban Kerja) terdiri dari 13 pernyataan, dan variabel dependen (Cedera tertusuk jarum suntik pada perawat) terdiri dari 9 pernyataan. variabel beban kerja, didapat nilai $\mathrm{r}$ tabel $=0.44$ dengan $\mathrm{df}=$ 18 pada tingkat kemaknaan 5\%. Hasil uji menunjukkan bahwa dari 13 pernyataan nilai $\mathrm{r}$ hitung $>\mathrm{r}$ tabel. Dan pada uji reliabilitas, didapatkan nilai alpha $=0.893>$
0,44. Ini menunjukkan bahwa nilai alpha $>r$ pada variable beban kerja sehingga tabel untuk pernyataan tentang beban kerja tersebut valid dan reliabel sehingga dapat dijadikan sebagai alat ukur dalam penelitian ini. Pada variabel cedera tertusuk jarm suntik pada perawat, didapat nilai $\mathrm{r}$ tabel $=$ 0.44 dengan $\mathrm{df}=18$ pada tingkat kemaknaan $5 \%$. Hasil uji menunjukkan bahwa dari 9 pernyataan nilai $r$ hitung $>r$ tabel. Dan pada uji reliabilitas, didapatkan nilai alpha $=$ $0.893>0,44$. Ini menunjukkan bahwa nilai alpha $>\mathrm{r}$ tabel untuk pertanyaan tentang Cedera tertusuk jarum suntik pada perawat tersebut valid dan reliabel sehingga dapat dijadikan sebagai alat ukur dalam penelitian ini

\section{HASIL dan PEMBAHASAN}

a. Karakteristik Responden Tabel 1. Distribusi berdasarkan umur responden di ruang rawat inap RSU GMIM Bethesda Tomohon

\section{Umur Responden}

\begin{tabular}{ccc} 
& $\mathrm{n}$ & $\%$ \\
\hline 21-30 Tahun & 28 & 43.8 \\
31-40 Tahun & 21 & 32.8 \\
41-50 Tahun & 15 & 24.3 \\
\hline Total & 64 & 100
\end{tabular}

Sumber : data Primer 2019

Berdasarkan hasil menunjukan bahwa umur terbanyak berada pada kelompok umur 21-30 tahun yakni sebnyak 28 responden $(43.8 \%)$. Penelitian ini sejalan dengan penelitian oleh Ermawati 2016 tentang Faktor - Faktor yang Berhubungan dengan Perilaku Pencegahan terjadinya Needle stick injury di Ruangan Rawat Inap Rumah Sakit X Jakarta menunjukan bahwa usia perawat berpengaruh terhadap keselamatan kerja agar selalu bekerja dalam keadaan sehat, nyaman, produktif dan sejahtra untuk dapat mencapai tujuan 
tersebut perlu kemauan, kemampuan dan kerjasama yang baik dari semua pihak. Umur mempunyai pengaruh yang sangat penting terhadap kejadian kecelakaan kerja dengan hasil bivariate menunjukan ada hubungan yang bermakna antara perilaku pencegahan terjadinya NSI di RS X dengan umur dengan hasil ( $\mathrm{p}=$ value 0.001$)$.

Penelitian ini bertolak dengan penelitian yang dilakukan Jefel 2015 tentang Hubungan umur dengan kejadian cedera tertusuk jarum suntik pada perawat di RS

Umum daerah Liunkendage Tahuna didapatkan hasil analisis uji chi-square didapatkan hasil dengan nilai $\mathrm{p}=0,571$ yang menunjukkan tidak terdapat hubungan yang bermakna antara faktor umur dengan kejadian cedera tertusuk jarum suntik pada perawat di rumah sakit Liunkendage Tahuna.

Tabel 2. Distribusi berdasarkan jenis kelamin responden di ruang rawat inap RSU GMIM Bethesda Tomohon

\begin{tabular}{ccc}
\hline $\begin{array}{c}\text { Jenis } \\
\text { Kelamin }\end{array}$ & $\mathrm{n}$ & $\%$ \\
\hline Perempuan & 41 & 64.1 \\
Laki-laki & 23 & 35.9 \\
\hline Total & 64 & 100
\end{tabular}

\section{Sumber : data Primer 2019}

Berdasarkan hasil menunjukan bahwa jenis kelamin terbanyak adalah perempuan yakni sebanyak 41 responden atau sebesar $64.1 \%$. Hasil penelitian ini sama dengan penelitian yang dilakukan oleh

(Wibowo, dkk 2013) Hubungan Karakteristik Perawat Dengan Penggunaan Sarung Tangan Pada Tindakan Invasif Di Ruang Rawat Inap RSUD Dr. H. Soewondo

Kendal, dengan hasil analisis bivariat menunjukkan tidak ada hubungan antara jenis kelamin $(\mathrm{p}=0,136)$ dengan penggunaan sarung tangan pada tindakan invasif.

Penelitian ini bertolak dengan penelitian yang dilakukan Jefel 2015 tentang Hubungan umur dengan kejadian cedera tertusuk jarum suntik pada perawat di RS

Umum daerah Liunkendage Tahuna didapatkan hasil analisis uji chi-square didapatkan hasil dengan nilai $\mathrm{p}=0,513$ yang menunjukkan tidak terdapat hubungan yang bermakna antara faktor jenis kelamin dengan kejadian cedera tertusuk jarum suntik pada

perawat di rumah sakit Liunkendage Tahuna

\section{b. Analisa Univariat}

Table 3. Distribusi berdasarkan beban kerja responden di ruang rawat inap RSU GMIM Bethesda Tomohon

\begin{tabular}{ccc}
\hline $\begin{array}{c}\text { Beban } \\
\text { Kerja }\end{array}$ & $\mathrm{n}$ & $\%$ \\
\hline Berat & 40 & 62.5 \\
Ringan & 24 & 37.5 \\
\hline Total & 64 & 100 \\
\hline
\end{tabular}

Sumber : data Primer 2019

Berdasarkan hasil uji univariat menunjukkan bahwa presentasi beban kerja di ruang rawat inap RSU GMIM Bethesda Tomohon sebagian besar berat yakni sebesar $62.5 \%$ dan beban kerja ringan sebesar $37.5 \%$. Beban kerja berat terjadi dikarenakan banyak perawat harus mengerjakan pekerjaan diluar pekerjaan perawat yaitu membersihkan ruangan dan mengganti laken pasien sehingga menambah beban kerja perawat. Beban kerja yang terlalu berlebihan akan menimbulkan stress mental atau reaksireaksi emosional seperti sakit kepala, gangguan pencernaan dan mudah marah.

Beban kerja terbagi menjadi 2 macam, yaitu beban kerja kulitatif dan beban kerja kuantitatif. Dimana beban kerja kualitatif adalah tingkat kesulitan atau kerumitan yang harus dilakukan oleh seorang perawat dan beban kerja kuantitatif 
merupakan banyaknya pekerjaan dan dilakukan oleh seorang perawat. Terdapat beberapa faktor yang mempengaruhi beban kerja yaitu faktor internal dan faktor eksternal. Faktor internal meliputi umur, jenis kelamin, berat badan, tinggi badan, gizi, kesehatan tubuh, motivasi, kepercayaan, kepuasan kerja dan keinginan. Sedangkan faktor eksternal meliputi, kegiatan organisasi kerja, kondisi lingkungan, tempat kerja dan tugas-tugas yang harus dikerjakan (Jantra, 2015).

Tabel 4. Distribusi berdasarkan tindakan pencegahan cedera tertusuk jarum di ruang rawat inap RSU GMIM Bethesda Tomohon

\begin{tabular}{lll}
\hline $\begin{array}{l}\text { Tindakan } \\
\text { Pencegahan }\end{array}$ & $\mathrm{n}$ & $\%$ \\
\hline Tidak Baik & 38 & 59.4 \\
Baik & 26 & 40.6 \\
\hline Total & 64 & 100 \\
\hline
\end{tabular}

Sumber : data Primer 2019

Berdasarkan hasil menunjukan bahwa mayoritas responden dengan tindakan pencegahan tidak baik yakni sebanyak 38 responden atau sebesar 59.4\%. Hasil penelitian ini sejalan dengan penelitian yang dilakukan oleh Tamaka (2017) tentang hubungan antara beban kerja dan perilaku aman dengan cedera tertusuk jarum suntik pada perawat di Rumah Sakit Bhayangkara Tk. III Manado, didapat hasil bahwa terdapat hubungan antara beban kerja dengan cedera tertusuk jarum suntik pada perawat dengan hasil $\mathrm{p}=0,001$.

Penelitian ini tidak sejalan dengan penelitian christiane, 2015 tentang faktor faktor yang berhubungan dengan tindakan pencegahan luka tusuk jarum suntik pada perawat di rumah sakit bayangkara TK. III manado dengan tindakan pencegahan yang paling banyak yaitu perawat yang memiliki tindakan pencegahan yang baik $(65,6 \%)$.
Berat ringannya beban kerja yang diterima oleh seseorang dapat menentukan berapa lama seseorang tersebut dapat melakukan pekerjaannya. Luka jarum suntik sering terjadi pada lingkungan pelayanan kesehatan yang melibatkan jarum sebagai alat kerjanya. Peristiwa ini menjadi perhatian bagi pelayanan rumah sakit karena risiko untuk menularkan penyakit melalui darah, seperti virus Hepatitis B (HBV), virus Hepatitis C (HCV), dan Human Immunodeficiency Virus (HIV) (Kemenkes RI ,2011).

\section{c. Analisis Bivariat}

Table 5. Hasil analisa hubungan beban kerja dengan tindakan pencegahan cedera tertusuk jarum di ruang rawat inap RSU GMIM Bethesda Tomohon

\begin{tabular}{|c|c|c|c|c|c|c|c|}
\hline \multirow{3}{*}{$\begin{array}{l}\text { Beban } \\
\text { kerja }\end{array}$} & \multicolumn{4}{|c|}{$\begin{array}{l}\text { Tindakan pencegahan } \\
\text { Cedera tertusuk jarun }\end{array}$} & \multicolumn{2}{|c|}{ Total } & \multirow[t]{2}{*}{$\rho$} \\
\hline & \multicolumn{2}{|c|}{ Tidak baik } & \multicolumn{2}{|c|}{ Baik } & \multirow[b]{2}{*}{$\mathrm{n}$} & \multirow[b]{2}{*}{$\%$} & \\
\hline & $\mathrm{n}$ & $\%$ & $\mathrm{n}$ & $\%$ & & & \multirow{3}{*}{0.000} \\
\hline Berat & 34 & $85 \%$ & 6 & $15 \%$ & 40 & $100 \%$ & \\
\hline ringan & 4 & $7 \%$ & 20 & $83 \%$ & 24 & $100 \%$ & \\
\hline
\end{tabular}

Sumber : data primer 2019

Berdasarkan hasil tabulasi silang menunjukan bahwa sebanyak 40 responden (100\%) yang mempunyai beban kerja berat terdapat, 34 responden (85\%) dimana beban kerja yang berat perawat yang memiliki beban berat melaporkan melakukan pencegahan yang tidak baik dan 6 responden (15\%) dengan pencegahan yang baik dan juga sebanyak 24 responden (100\%) yang mempunyai beban kerja ringan terdapat, 4 responden (17\%) dengan pencegahan tidak baik dan 20 responden dengan pencegahan yang baik. Hasil analisis dengan menggunakan uji ChiSquare memperoleh nilai signifikan $=0.000$ atau lebih kecil dari nilai $\alpha 0.05$, maka dengan demikian dapat disimpulkan bahwa terdapat hubungan beban kerja dengan pencegahan tidak baik di ruang rawat inap RSU GMIM Bethesda Tomohon dimana perawat melebihi beban kerja berat, dengan nilai Odds ratio 28.333 yang berarti 
semakin tinggi atau berat beban kerja yang dimiliki perawat maka akan mempengaruhi 28.333 kali lipat terhadap resiko cedera tertusuk jarum. Hasil penelitian ini sejalan dengan penelitian yang telah dilakukan oleh Romario 2015, dengan hasil penelitian membuktikan bahwa terdapat hubungan yang bermakna antara beban kerja yang lebih terhadap tingkat kecelakaan kerja di ruang keperawatan RSUD Yogyakarta, yang memperoleh nilai $\mathrm{p}<0,05$.

\section{SIMPULAN}

Terdapat hubungan antara beban kerja dengan tindakan pencegahan Cedera tetusuk jarum suntik pada perawat di RSU Bethesda GMIM Tomohon yang di dapat dari hasil uji analisis chi square dengan nilai signifikan 0,000. Dari hasil penelitian responden sebanyak 64 perawat menunjukan bahwa kebanyakan responden memiliki beban kerja yang berat yaitu sebanyak 40 pearawat $(62,5 \%)$. Sedangkan sebanyak 64 perawat responden di ruang rawat inap RSU Bethesda GMIM Tomohon menunjukan bahwa kebanyakan responden memiliki tindakan pencegahan Cedera tertusuk jarum suntik tidak baik sebanyak 38 perawat $(59,4 \%)$.

\section{DAFTAR PUSTAKA}

\section{Asmadi. (2008). Teknik}

Prosedural Keperawatan : Konsep

Dan Aplikasi Kebuthan Dasar Klien. Jakarta :

Salemba Medika

Ermawati, Arlis (2016) faktor-faktor yang berhubungan dengan perilaku pencegahan terjadinya needle stick injury di ruangan rawat inap Rumah sakit X Jakarta. Jurnal kesehatan masyarakat, (4) 3.

Jantra, (2015). Pengaruh faktor internal dan eksternal karyawan terhadap produktivitas kerja, jurnal
Jefel, (2015) Faktor-faktor yang berhubungan dengan kejadian cedera tertusuk jarum suntik pada perawat di Rumah Sakit Liunkendage Tahuna, Jurnal

Kemenkes , (2011). InfoDATIN Pusat Data Dan Informasi Kementerian Kesehatan RI, Situasi dan Analisis Hepatitis

Pangalila, M. Cheisy. (2017) Hubungan Antara Beban Kerja Dengan Cedera Tertusuk Jarum Suntik Pada Perawat Di Rumah Sakit GMIM Kalooran Amurang. Program Study Fakultas Kesehatan Masyarakat Universitas Samratulangi.

Romario. (2015) hubungan yang bermakna antara beban kerja yang lebih terhadap tingkat kecelakaan kerja di ruang keperawatan RSUD Yogyakarta.

Runtu, V. V, \& Hamel, R. (2018). Hubungan Beban Kerja Fisik Dengan Stres Kerja Kasih Manado, 6.

Siswanto, Susila, \& Suyanto. (2016) Metode Penelitian Kesehatan dan Kedokteran. Yogyakarta: Nuha Medika.

Sumangando, M., Rottie, J., \& Lolong, J. (2017). Hubungan beban kerja perawat dengan kejadian low back pain (LBP) pada perawat pelaksana di RS TK. III R.W Mongonsidi Manado. Ejoural Keperawatan(e-Kp), 5(1), 1-9.

Tamaka, (2017). Hubungan antara beban kerja dan perilaku aman dengan Cedera tertusuk jarum suntik pada perawat di Rumah Sakit Bhayangkara Tk. III Manado, jurnal

Wibowo S. Aditya. (2013) Hubungan karakteristik perawat dengan penggunaan sarung tangan pada tindakan invasive di ruang rawat inap RSUD dr. H. Soewando Kendal 
e-journal Keperawatan (e-Kep) Volume 7 nomor 1, Mei 2019 